\title{
$\mathrm{Cu}-3.5 \mathrm{wt} \% \mathrm{Ti}$ 합금의 석출 거동에 미치는 시효 전 가공의 영향 조민아 ${ }^{1,2} \cdot$ 최은애 ${ }^{1} \cdot$ 안지혁 ${ }^{1} \cdot$ 손영국 ${ }^{2} \cdot$ 김광호 $^{2} \cdot$ 이재현 ${ }^{3} \cdot$ 사토시 셈보시 ${ }^{4} \cdot$ 한승전 $^{1, *}$ \\ 1 한국기계연구원 부설 재료연구소 재료공정혁신연구본부 \\ 2부산대학교 재료공학과 \\ 3창원대학교 신소재공학부 \\ 도호쿠대학교 금속재료연구소
}

\section{Effect of Prior Cold Working before Aging on the Precipitation Behavior in a Cu-3.5 wt\% Ti Alloy}

\author{
Minah Jo ${ }^{1,2}$, Eun-Ae Choi ${ }^{1}$, Jee Hyuk Ahn', Young Guk Son ${ }^{2}$, Kwangho Kim ${ }^{2}$, \\ Jehyun Lee ${ }^{3}$, Satoshi Semboshi ${ }^{4}$, and Seung Zeon Han ${ }^{1, *}$ \\ ${ }^{1}$ Materials Processing Innovation Research Division, Korea Institute of Materials Science, Changwon 51508, Republic of Korea \\ ${ }^{2}$ School of Materials Science and Engineering, Pusan National University, Busan 46241, Republic of Korea \\ ${ }^{3}$ Department of Materials Science and Engineering, Changwon National University, Changwon 51140, Republic of Korea \\ ${ }^{4}$ Trans-Regional Corporation Center for Industrial Materials Research, Tohoku University, 599-8351, Japan
}

\begin{abstract}
Cu}$-Ti alloys were strengthened by $\mathrm{Cu}_{4} \mathrm{Ti}$ intermetallic compound precipitation in a $\mathrm{Cu}$ matrix during aging. The $\mathrm{Cu}-3.5 \mathrm{wt} \% \mathrm{Ti}(\mathrm{Cu}-4.6 \mathrm{at} \% \mathrm{Ti})$ alloys without deformation and with uniform and nonuniform deformation were aged at $450{ }^{\circ} \mathrm{C}$ for various times after solution treatment at $885^{\circ} \mathrm{C}$. The uniformly and non-uniformly deformed alloys show slip and shear band formation in the matrix, respectively. The deformation bands, slip or shear bands, were still maintained even after 12 hours of aging at $450{ }^{\circ} \mathrm{C}$. The conductivity of all the specimens continuously increased, but the hardness reached the peak value and then decreased during aging. The hardness and conductivity of the specimen with shear bands had a higher value than the specimens without deformation and with slip bands. Additionally, the time to reach peak hardness of the specimen with shear bands was shortened to 30 minutes compared to 720 and 1440 minutes for specimens with slip bands and without deformation bands, respectively. The highest combination value of conductivity and hardness, 16.8\% IACS and $302 \mathrm{Hv}$, was obtained in the specimen with shear bands after aging for 360 minutes.
\end{abstract}

(Received September 27, 2018; Accepted October 19, 2018)

Keywords: $\mathrm{Cu}-\mathrm{Ti}$ alloy, aging, $\mathrm{Cu}_{4} \mathrm{Ti}$ intermetallic compound, precipitation hardening, electrical conductivity.

\section{1. 서 론}

구리 합금은 다른 합금에 비해 높은 전도도를 가진 구리 가 기지(matrix)를 이룬다. 따라서, 기계적 특성의 향상을 위한 합금화 또는 가공 열처리 공정 후에도 다른 합금에 비해 상대적으로 높은 전도도를 가진다. 이에 따라 신호 또는 전력을 이동시키는 전선, 커넥터 등 전기 및 전자부

- 조민아: 석사과정, 최은애·안지혁·한승전: 연구원, 손영국·김광호·이재현·사토시 셈보시: 교수

*Corresponding Author: Seung Zeon Han

[Tel: +82-55-280-3331, E-mail: szhan@kims.re.kr]

Copyright (C) The Korean Institute of Metals and Materials
품의 원재료에 동합금을 사용할 수 밖에 없다. 높은 전도 도를 가진 동합금을 강화시키는 방법은 고용, 석출, 분산 그리고 결정립미세화 등이 있지만 이러한 강화 방법은 전 도도 감소를 야기하기도 한다 [1-10]. 그런데, 구리 합금이 실제로 산업계에 응용되기 위해서는 생산에 있어서 경제성 을 가짐과 동시에 기계적 특성과 전기 전도도가 적절한 균 형을 이루어야 한다. 여러 강화기구에서 비교적 높은 전도 도와 강도를 동시에 구현하는 방법은 석출강화라고 할 수 있다 [4-16]. 일반적으로 잘 알려진 석출강화형 동합금은 $\mathrm{Cu}-\mathrm{Ni}-\mathrm{Si}$ [4-8], $\mathrm{Cu}-\mathrm{Fe}$ [11,12], $\mathrm{Cu}-\mathrm{Be}$ [13,14] 그리고 $\mathrm{Cu}-\mathrm{Ti}$ [15-18]합금이 있으며, 그 중에서도 $\mathrm{Cu}-\mathrm{Ti}$ 합금은 
다른 합금에 비해 $1 \mathrm{GPa}$ 에 달하는 높은 강도와 비교적 높은 전도도를 가지기 때문에 커넥터 또는 전도성 스프링 소재로써 현재 사용되고 있으며, 고강도 및 고전도화를 위 한 다양한 연구가 다각적으로 계속해서 진행되고 있다 [15-18].

과포화 고용된 $\mathrm{Cu}-\mathrm{Ti}$ 합금은 시효 시 스피노달 분해를 거쳐 준안정상인 $\beta^{\prime}-\mathrm{Cu}_{4} \mathrm{Ti}$ (tetragonal structure with a spacing group of $\mathrm{I} 4 / \mathrm{m})$ 이 생성되고, 시효를 계속할 경우, 안정상인 $\beta-\mathrm{Cu}_{4} \mathrm{Ti}$ (orthorhombic structure with a spacing group of $\mathrm{Pmmn}$ )으로 변태된다. 준안정상인 $\beta^{\prime}-\mathrm{Cu}_{4} \mathrm{Ti}$ 은 시효 시 결정립 내 또는 입계에 석출되며, 시효가 더욱 진행될 경우는 입계에서 라멜라 형태를 가지는 안정한 $\beta$ $\mathrm{Cu}_{4} \mathrm{Ti}$ 으로 변태된다. 전자를 연속 석출(continuous precipitation), 그리고 후자를 불연속 석출(discontinuous precipitation)이라고 한다. $\mathrm{Cu}-\mathrm{Ti}$ 합금은 비교적 다른 동합 금에 비해 적절한 강도와 전도도 조합을 얻기 위해선 장시 간의 석출 시간을 요하고 전기 전도도가 낮은 단점이 있다 [18-21]. 이를 위해선 석출을 가속화하는 방안, 즉 새로운 합금 설계 또는 가공 열처리 기술의 도입이 필요하다. 본 연구는 결정립계, 전위(dislocation) 또는 전위의 집합체라 고 할 수 있는 전단 밴드(shear band)가 불균일 핵생성 사이트(heterogeneous nucleation site)로 작용될 수 있다는 것에 착안하여 전위 또는 전단 밴드를 포함한 불균일 가공 조직을 가진 $\mathrm{Cu}-3.5 \mathrm{wt} \% \mathrm{Ti}(\mathrm{Cu}-4.6 \mathrm{at} \% \mathrm{Ti})$ 합금을 제조 하였다. 용체화 처리된 합금 내부에 균일 변형(uniform deformation)을 부가하여 대표적인 내부 결함으로 전위를 생성시켰고, 다른 합금은 불균일 변형(non-uniform deformation)을 부여하여 내부에 전단 밴드를 포함한 불균 일 가공 조직을 생성시켰다. 용체화 처리된 $\mathrm{Cu}-3.5 \mathrm{wt} \%$ $\mathrm{Ti}$ 합금, 전위가 지배적으로 생성된 합금, 그리고 전위는 물론 다량의 전단 밴드가 생성된 합금을 동일한 온도에서 시효하여, 균일 및 불균일 핵생성에 따른 미세조직 변화를 관찰하고 그에 따른 기계적 또는 전기적 특성을 확인하였 다. 특히 불균일 핵생성중에도 전위 주도와 전단 밴드 주 도의 시효 거동을 관찰하였다. 그 결과 시효 전 가공을 행 한 합금의 최고 경도 도달시간이 감소하였다. 용체화 처리 후, 가공없이 시효한 합금에서는 최고 경도와 전도도는 $275 \mathrm{Hv}, 15 \%$ IACS이고 이에 도달된 시간은 1140 분이며, 전위 주도 불균일 핵생성이 일어난 합금의 경우 경도는 $295 \mathrm{Hv}$, 전도도는 $15 \% \mathrm{IACS}$ 으로 도달 시간은 720 분이었 다. 그리고 전단 밴드가 포함된 불균일 핵생성이 일어난 합금의 경우, $340 \mathrm{Hv}, 9.7 \% \mathrm{IACS}$ 를 나타내었고 최고 경 도에 도달된 시간은 30 분이었다. 이는 전위 특히 합금 내
전단 밴드가 시효를 가속화한다는 것을 의미한다. 이러한 결과가 도출된 이유를 밝히고자 본 연구는 시효에 미치는 시효 전 소성 가공에 의해 생성된 결함이 어떻게 시효 거 동을 변화시키는 가를 관찰하였다. 또한 생성된 석출물의 형상과 분포를 관찰하여 시효 전 가공도가 $\mathrm{Cu}-\mathrm{Ti}$ 합금의 기계적 그리고 전기적 특성에 미치는 영향을 고찰하였다.

\section{2. 실험방법}

본 연구에서는 순도 $99.99 \% \mathrm{Cu}$ 와 $\mathrm{Cu}-50 \mathrm{wt} \% \mathrm{Ti}$ 모 합금을 사용하여 $\mathrm{Cu}-3.5 \mathrm{wt} \% \mathrm{Ti}(\mathrm{Cu}-4.6 \mathrm{at} \% \mathrm{Ti})$ 합금을 $\mathrm{Ar}$ 가스 분위기에서 진공 유도 용해를 이용하여 주조하여, 두께 $30 \mathrm{~mm}$, 폭 $60 \mathrm{~mm}$ 그리고 길이 $130 \mathrm{~mm}$ 시편을 제 작하였다. 주조된 잉곳은 $850{ }^{\circ} \mathrm{C}$ 에서 24 시간 동안 균질화 처리를 한 후, 직경 $20 \mathrm{~mm}$ 그리고 길이 $100 \mathrm{~mm}$ 봉상 형태의 시험편으로 가공하였다. 이 시편을 단면적 감소율 $75 \%$ 까지 상온에서 스웨이징(swaging)하여 최종적으로 $\Phi 10 \mathrm{~mm} \times 400 \mathrm{~mm}$ 의 봉재 시편을 제조하였다. 스웨이징 된 시편의 가공 이력(working history)을 제거하기 위하여 $885^{\circ} \mathrm{C}$ 의 대기에서 1 시간 동안 열처리 후 수냉 즉 용체화 처리를 시행하였다. 용체화 처리 후 시효를 시행하는데, 시 효에 미치는 가공(working)의 효과를 고찰하기 위해, 가공 공정을 단면적 감소율 $15 \%$ 와 $75 \%$, 두 개의 가공도로 나 누어 시행하였다. 용체화 처리된 $\mathrm{Cu}-3.5 \mathrm{wt} \% \mathrm{Ti}$ 합금을 상온에서 인장시험(ASTM E8M규격)하였으며, 그 결과 그 림 1 에 진응력 $(\sigma)$-진변위 $(\varepsilon)$ 및 진변위 $(\varepsilon)$ 에 따른 $1 / \sigma(\mathrm{d \sigma} /$ $\mathrm{d} \varepsilon)$ 변화 그래프를 각각 나타내었다. 여기서 $1 / \sigma(\mathrm{d} \sigma / \mathrm{d} \varepsilon)$ 가 1 보다 클 때는 현재 응력 대비 가공 경화가 큰 경우인 균 일 변형(uniform deformation)을 의미하고 1 보다 작을 경 우는 현재 응력보다 가공 경화가 작다는 것으로 불균일 변 형(non-uniform deformation)이 야기된다는 것을 의미한다. 즉 본 용체화 처리한 $\mathrm{Cu}-3.5 \mathrm{wt} \% \mathrm{Ti}$ 합금의 응력(stress)변위(strain)는 실제적으로 균일 변형 즉 전위(dislocation) 에 의해 야기되는 변위의 한계는 진변형으로 $24.5 \%$, 그리 고 공칭변형으로 $27.8 \%$ 라는 의미가 된다. 용체화 처리된 $\mathrm{Cu}-3.5 \mathrm{wt} \% \mathrm{Ti}$ 합금을 상온에서 가공하였을 경우, $27 \%$ 이하의 변위에서는 주로 전위에 의해서 변형이 일어난다는 것을 의미한다.

즉, 본 합금에 적용된 단면적 감소율 $15 \%$ 는 진변형율 $16.25 \%$ 로 변형 후 합금 내 발생된 결함은 전위뿐이라는 것을 의미한다. 그리고 균일 변형 한계 이상의 변형 즉 가 공도에서는 전위 이외에 전단 밴드(shear band) 등의 불균 일 결함으로 소성 가공 된다는 것을 의미한다. 이러한 점 

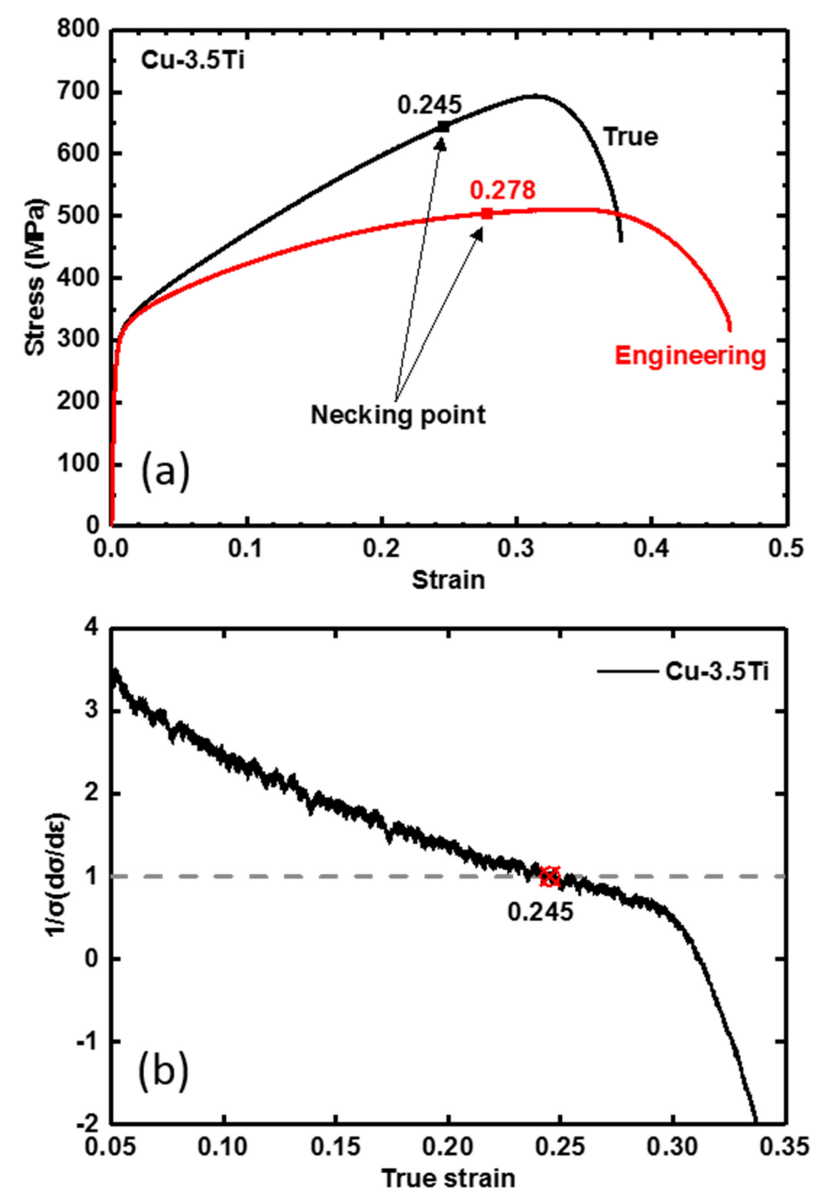

Fig. 1. (a) Engineering and true stress-strain curves of solution treated $\mathrm{Cu}-3.5 \mathrm{Ti}$ alloy, (b) $1 / \sigma(\mathrm{d} \sigma / \mathrm{d} \varepsilon)$ vs true $\operatorname{strain}(\varepsilon)$.

에서 시효 전 소성 가공에 의해 발생한 결함(전위, 전단 밴드)을 효과적으로 구분하기 위해서 단면적 감소율 $15 \%$ 로 봉상 압연 가공(groove rolling)하여 전위만 생성시켰다. 또한 전위 외에 불균일 가공의 대표적인 결함인 전단 밴드 를 생성시키기 위해서 단면적 감소율 $75 \%$ 로 봉상 압연을 시행하였다. 본 연구에서는 비교재로서, 용체화 처리한 시 편과, 연구 대상 소재로서, $15 \%$ 그리고 $75 \%$ 단면적 감소 율로 성형한 시편을 $450{ }^{\circ} \mathrm{C}$ 에서 시효하여 석출물의 균일 핵생성(homogeneous nucleation) 그리고 전위와 전단 밴드 가 불균일 핵생성(heterogeneous nucleation)을 일으킨다는 가정 아래 시효 시 석출 거동과 경도 및 전기 전도도 변 화를 살펴보았다. 이러한 일련의 실험과정을 다음 그림 2 에 나타내었다.

각각의 조건에서 시효 된 시편을 약 $5 \mathrm{~mm}$ 의 길이로 절 단한 후, 에폭시 수지로 콜드 마운팅(cold mounting) 후 자동 연마기(auto polisher, Allied, Dualprep 3-AP4 power head)를 사용하여 기계 연마 하였다. 연마한 후
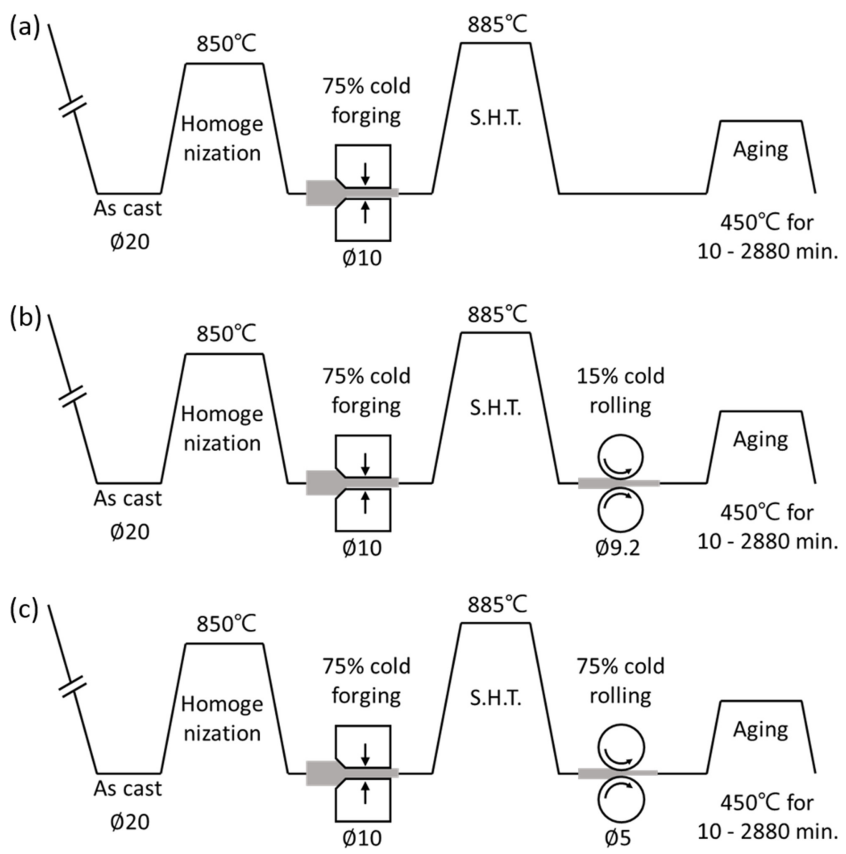

Fig. 2. Schematic diagrams of thermo-mechanical treatment processes for (a) no prior cold working, (b) 15\% prior cold working and (c) $75 \%$ prior cold working of $\mathrm{Cu}-3.5 \mathrm{Ti}$ alloy.

$30 \% \mathrm{HNO}_{3}$ 수용액을 이용하여 $0{ }^{\circ} \mathrm{C}$ 에서 7초 동안 에칭 하여 광학 현미경(optical microscope, OM, OLYMPUS, GX51)으로 미세조직을 관찰하였다. 또한 마운팅을 하지 않 은 시편을 $40 \% \mathrm{H}_{3} \mathrm{PO}_{4}$ 수용액에서 $2 \mathrm{~V}$ 조건으로 약 3초 동안 전해 에칭을 시행 후 전계 방사형 주사전자현미경 (field emission scanning electron microscope, FE-SEM, $\mathrm{JEOL}, \mathrm{JSM}-7001 \mathrm{~F})$ 을 이용하여 미세조직을 관찰하였다. 기 계적 특성은 인장 시험기(tensile tester, Instron, 5982)를 이용하여 $25 \mathrm{~mm}$ 신율계(extensometer)를 사용하여 $2 \mathrm{~mm} /$ $\min$ 의 속도로 인장 시험 하였다. 그리고 미소경도계(microVickers hardness, Matsuzawa, MX70)를 이용하여 하중 $0.2 \mathrm{kgf}$ 으로 경도를 측정하였다. 전기 전도도는 double bridge 방법으로 시편의 전기저항을 측정 후 \% IACS(The International Annealed Copper Standard)로 나타내었다.

\section{3. 결 과}

그림 3 은 $850{ }^{\circ} \mathrm{C}$ 에서 용체화 처리, 그리고 용체화 처리 후 단면적 감소율 $15 \%$ 와 $75 \%$ 로 소성 가공한 $\mathrm{Cu}-3.5$ $\mathrm{wt} \% \mathrm{Ti}$ 합금의 미세조직을 각각 나타내었다.

그림에서 나타낸 바와 같이, 용체화 처리된 시편과 달리 그림 3의 (b)와 (c)는 변형대(deformation band)가 생성된 


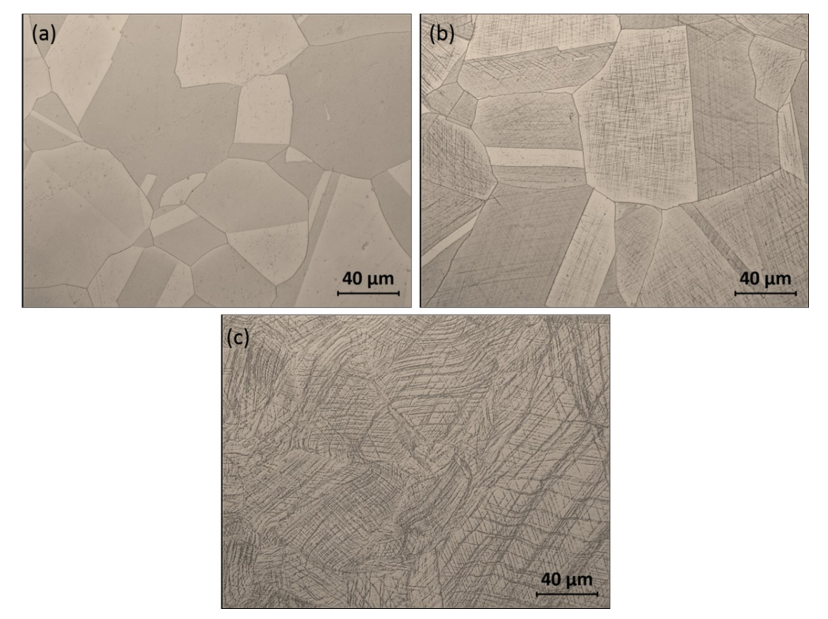

Fig. 3. Microstructures after (a) S.H.T. for 1 hour at $885^{\circ} \mathrm{C}$, (b) $15 \%$ groove rolling and (c) $75 \%$ groove rolling of $\mathrm{Cu}-3.5 \mathrm{Ti}$ alloy.

것을 알 수 있다. 그리고 $15 \%$ 단면적 감소율로 상온 성 형 가공된 시편의 경우는 슬립 밴드(slip band)가 결정립 내에서 생성되었음을 볼 수 있는데, 이는 성형이 전위로만 이루어졌다는 것을 의미한다. 또한 인장시험결과 그림 1 에
서 보인 바와 같이 균일 변형 한계를 꽤 초과한 $75 \%$ 단 면적 감소율로 소성 가공된 시편에서는 전단 밴드가 관측 됨을 알 수 있었다. 여기서 슬립 밴드와 전단 밴드는 각 밴드가 결정립계 관통 여부에 따라 명확히 구분된다. 즉 슬립 밴드의 경우, 인접한 결정립에서 슬립면이 크게 어긋 났을 때 슬립이 한 결정립에서 다른 결정립으로 전파되기 힘들다. 따라서 그림 3 (b)에 나타낸 바와 같이 각 결정립 내에서 슬립 밴드가 독자적으로 생성된다. 특히 쌍정 계면 에서는 슬립 방향이 크게 어긋나 있는 것을 확인할 수 있 다. 그런데 그림 3 (c)에 나타낸 전단 밴드의 경우는 주어 진 응력의 방향에 지배적으로 전단 변형이 이루어지기 때 문에 결정립계를 관통하는 밴드가 많이 관찰된다.

그림 4는 용체화 처리된 시편 그리고 슬립 밴드와 전단 밴드를 가진 시편을 $450{ }^{\circ} \mathrm{C}$ 에서 30 분, 12 시간 그리고 48 시간을 시효한 경우의 미세조직을 나타내었다. 시효 전 가 공을 시행하지 않은 시편과 시효 전 $15 \%$ 단면적 감소율 로 소성 가공한 시편의 경우, 12 시간 시효 후 일부 결정 립계에 불연속 석출된 영역이 발생하였고 이 두 시편을 48시간 시효했을 경우, 불연속 석출 영역이 증가되었음을
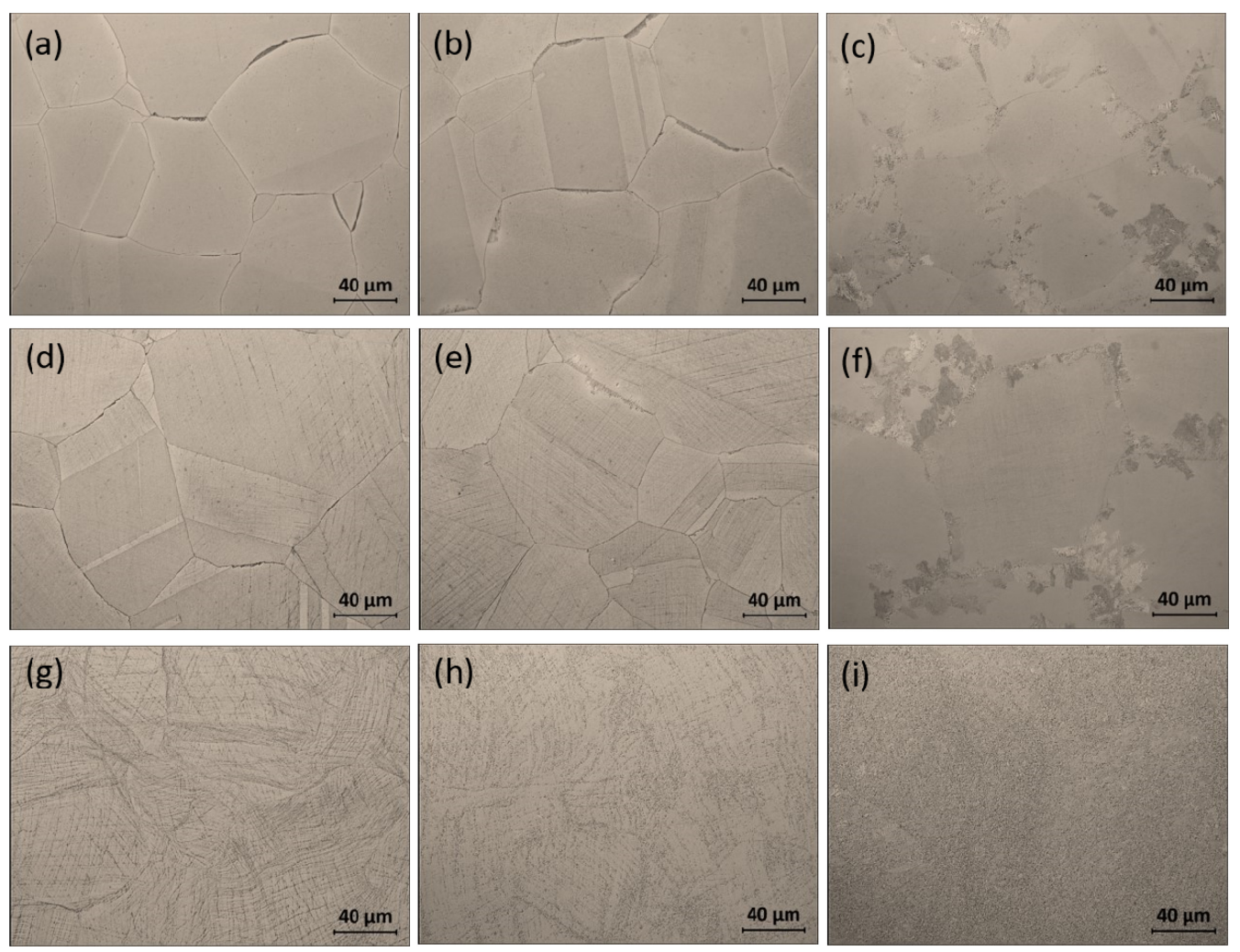

Fig. 4. Microstructures of aged specimens without prior cold work before aging for (a) 30 minutes, (b) 12 hours and (c) 48 hours. Aged specimens with $15 \%$ groove rolled before aging for (d) 30 minutes, (e) 12 hours and (f) 48 hours. Aged specimens with $75 \%$ groove rolled before aging for (g) 30 minutes, (h) 12 hours and (i) 48 hours, respectively. 

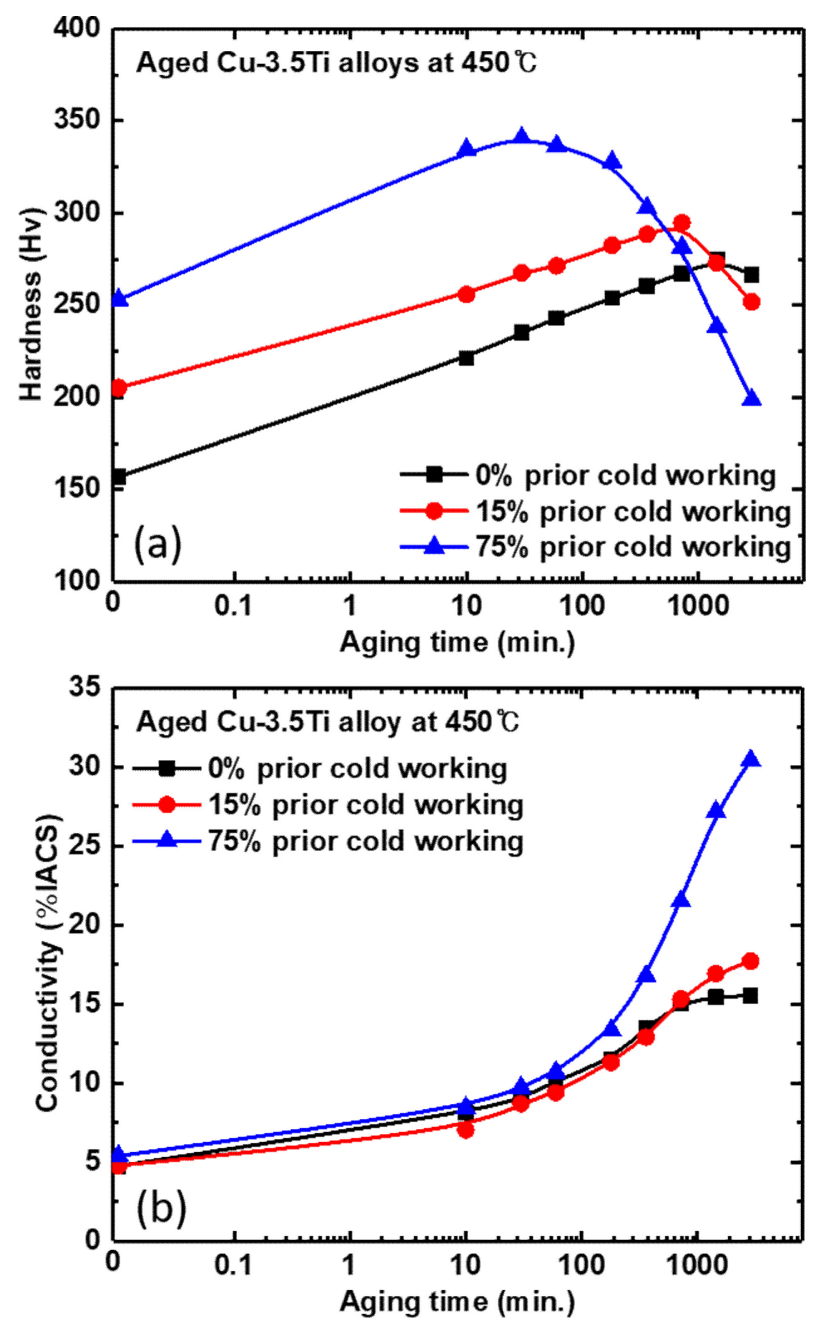

Fig. 5. (a) Vickers hardness and (b) electrical conductivity changes of $\mathrm{Cu}-3.5 \mathrm{Ti}$ alloy with increasing aging time at $450{ }^{\circ} \mathrm{C}$.

알 수 있었다. 반면 시효 전 $75 \%$ 단면적 감소율로 가공 한 시편은 48시간 후에도 불연속 석출된 영역이 관측되지 않았다. 그런데 본 결과에서 중요한 점은 시효 전 가공을 시행한 시편을 12 시간 열처리 해도 가공 조직이 유지되고 있다는 것이다. $\mathrm{Cu}-\mathrm{Ti}$ 이원계 상태도에서 $\mathrm{Cu}-3.5 \mathrm{wt} \% \mathrm{Ti}$ 합금의 고상선은 $1000{ }^{\circ} \mathrm{C}$ 이다. 고상선을 이 합금의 융점으 로 판단할 때 본 연구의 시효 온도인 $450^{\circ} \mathrm{C}$ 는 0.57 homologous 온도( $\mathrm{T}$ (aging temperature, $\mathrm{K}) / \mathrm{T}_{\mathrm{m}}$ (melting point, K))에 달하고, 이는 확산이 충분히 진행될 수 있는 온도라고 판단된다. 그럼에도 불구하고 12 시간의 열처리 후에도 가공 조직이 잔존한다는 것은 다른 동합금에 비해 가공된 $\mathrm{Cu}-\mathrm{Ti}$ 합금의 열적 안정성이 매우 높다는 것을 의 미한다.

그림 5 는 $\mathrm{Cu}-3.5 \mathrm{wt} \%$ Ti합금의 용체화 처리된 시편과
시효 전 $15 \%$ 그리고 $75 \%$ 가공된 시편을 $450^{\circ} \mathrm{C}$ 에서 시 효했을 때 시간의 증가에 따른 경도(그림 5 (a))와 전도도 (그림 5 (b))를 각각 나타내었다. 시효 시 경도는 시편의 종류에 관계없이 시효 시간이 증가함에 따라 최고 경도 (peak hardness)를 보이다가 감소하는 경향을 보였다. 전도 도의 경우는 시효 시간의 증가에 따라 점진적인 증가를 보 였다. 또한 시효 전 가공도가 클수록 장시간 시효 시 높은 전도도를 가지는 것으로 나타났다. 특히 최고 경도는 시효 전 단면적 감소율 $75 \%$ 로 가공된 시편의 경우 약 $340 \mathrm{Hv}$ 의 값을 보였고 이는 용체화 처리만 시행한 시편에 비해 $65 \mathrm{Hv}$ 나 높은 결과이다. 또한 최고 경도에 도달하는 시간 은 단면적 감소율 $15 \%$ 의 경우는 720 분, $75 \%$ 의 경우는 30 분으로써 용체화 처리 후 바로 시효한 시편의 1440 분과 비교했을 때, 시효 전 가공도가 증가할수록 기하급수적으 로 석출 속도가 증가되었음을 확인할 수 있었다. 본 연구 에서 전도도와 경도의 최고 조합(경도와 전도도의 곱이 최 고인 값)인 $16.8 \% \mathrm{IACS}$ 와 $302 \mathrm{Hv}$ 는 전단 밴드를 가진 시편을 360 분 시효했을 때 얻어졌다. 이 상의 결과를 간단 하게 요약하면 $\mathrm{Cu}-3.5 \mathrm{wt} \% \mathrm{Ti}$ 합금을 시효했을 때, 용체 화 처리 후 시효 전 가공은 시효 시 최고 경도의 크기를 증가시키고 최고 경도에 도달하는 시간을 급격하게 감소시 킴을 보였다.

\section{4. 고 찰}

시효 전 가공은 그림 3에 나타낸 바와 같이 가공도에 따라 균일 변형(uniform deformation)에 의한 슬립 밴드 (slip band)와 불균일 변형(non-uniform deformation)에 의 해 전단 밴드(shear band)를 생성시킨다. 이러한 가공 조직 은 일종의 결함으로써 시효 시 불균일 핵생성 사이트 (heterogeneous nucleation site)로 작용할 것으로 예상된다. 일반적인 동합금에서 시효 시, 시효 전 가공도에 따른 석 출 효과가 미미하거나 그다지 크지 않은 것으로 알려져 있 다 [22-27]. 그런데 본 $\mathrm{Cu}-\mathrm{Ti}$ 합금의 경우, 그림 4에 나 타낸 바와 같이 $450^{\circ} \mathrm{C}$ 의 비교적 높은 온도, 즉 $0.57 \mathrm{~T} /$ $\mathrm{T}_{\mathrm{m}}$ 에서 12 시간의 열처리에도 슬립 또는 전단 밴드의 가공 조직이 제거되지 않음이 확인되었다. 즉 장시간의 시효에 도 이러한 가공대(deformation band)가 사라지거나 이동하 기 용이하지 않다는 것이다. 즉 이동이 어려운 가공대는 장시간의 시효에도 불균일 핵생성 사이트로써 역할을 충분 이 수행할 수 있다는 의미를 가진다.

다음 그림 6 은 $\mathrm{Cu}-3.5 \mathrm{wt} \% \mathrm{Ti}(\mathrm{Cu}-4.6 \mathrm{at} \% \mathrm{Ti})$ 합금의 용체화 처리, 시효 전 단면적 감소율 $15 \%, 75 \%$ 로 가공한 

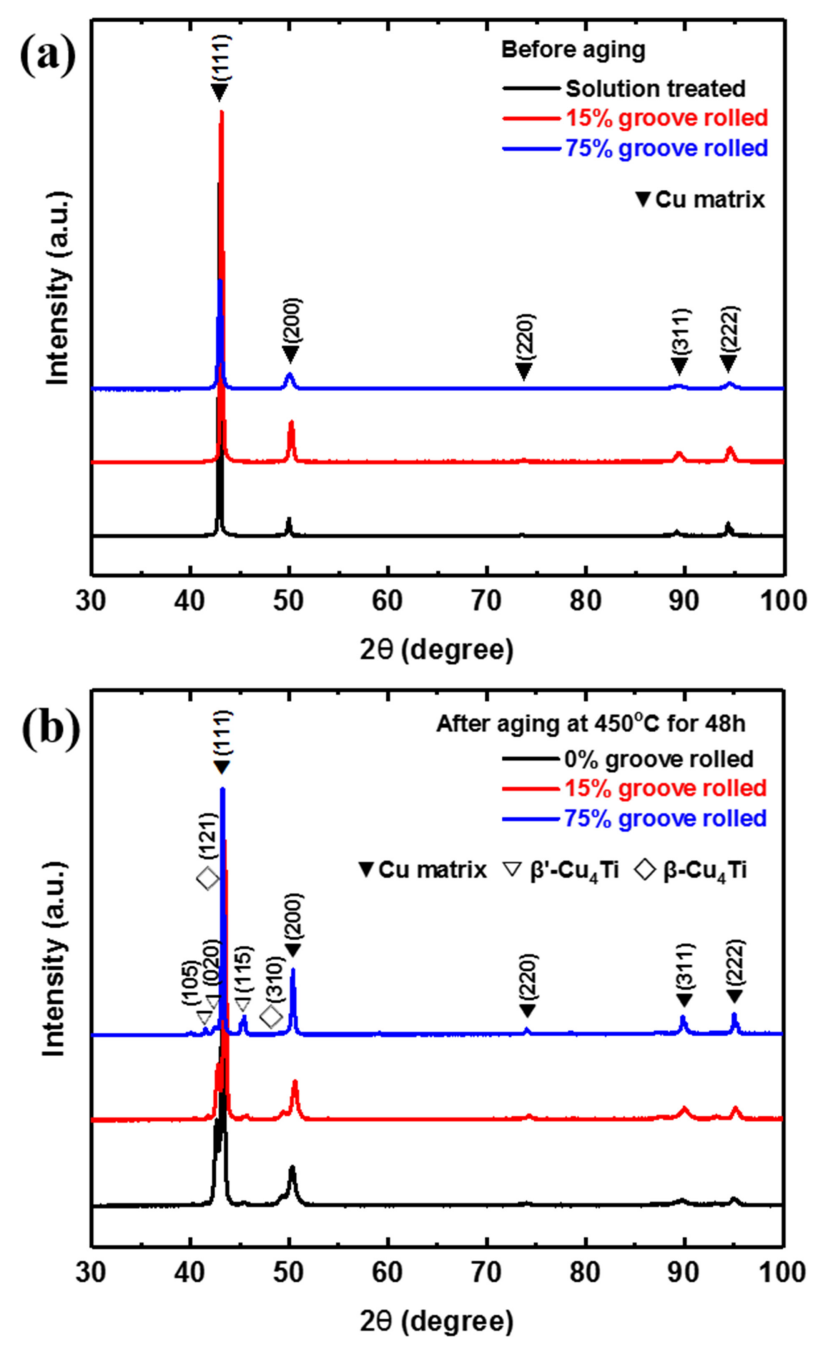

Fig. 6. XRD results of (a) solution heat treated and 15\%, 75\% groove rolled specimens, (b) aged after solution heat treated and $15 \%, 75 \%$ groove rolled specimens at $450{ }^{\circ} \mathrm{C}$ for 48 hours.

직후(그림 6(a)), 그리고 시효 전 가공하지 않은 시편과 $15 \%, 75 \%$ 가공한 시편을 $450{ }^{\circ} \mathrm{C}$ 에서 48 시간 시효한 후 (그림 6(b)) X-ray 분석한 결과를 각각 나타내었다. 그림에 서 알 수 있듯이 용체화 처리 또는 소성가공된 시편에서 $\mathrm{Cu}$ 기지 외에 다른 상들은 확인되지 않았다. 그런데 48시 간 시효했을 경우, 준안정상인 $\beta^{\prime}-\mathrm{Cu}_{4} \mathrm{Ti}$ 의 생성과 동시에 안정상인 $\beta-\mathrm{Cu}_{4} \mathrm{Ti}$ 도 생성된것이 확인되었다. $\beta-\mathrm{Cu}_{4} \mathrm{Ti}$ 은 그 림 4(c)와 (f)에서 확인된 불연속 석출물(discontinuous precipitation)로 사료된다.

그림 7은 시효 전 가공 유무에 따른 시편의 $450{ }^{\circ} \mathrm{C}$ 에서 12 시간과 48시간의 시효 후 미세조직을 나타내었다. 그림 에서 나타낸 바와 같이 본 연구의 합금을 시효 시, 전형적 인 $\beta^{\prime}-\mathrm{Cu}_{4} \mathrm{Ti}$ 화합물 [19-21]이 석출되는 것을 확인하였다.
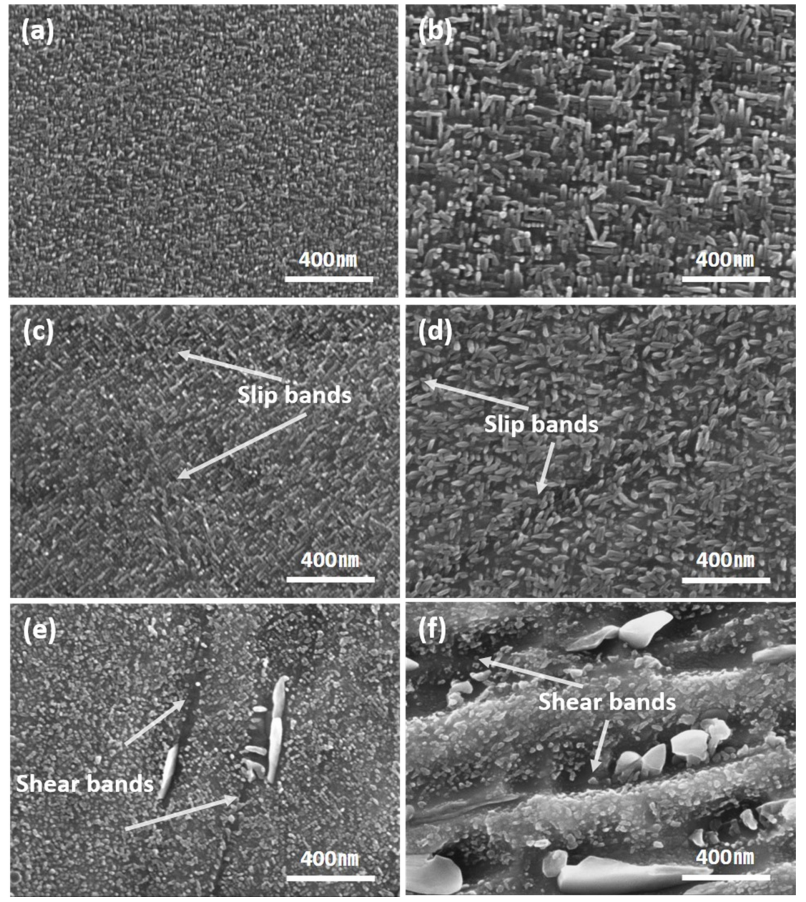

Fig. 7. Microstructures of specimens aged at $450{ }^{\circ} \mathrm{C}$ for (a) 12 hours and (b) 48 hours after solution treated, and aged for (c) 12 hours and (d) 48 hours after $15 \%$ area reduction, and aged for (e) 12 hours and (f) 48 hours after $75 \%$ area reduction, respectively.

용체화 처리 후 바로 시효된 합금의 경우 일정한 방향성을 가진 정방형 형태의 입자가 생성되었고 이는 $\beta^{\prime}-\mathrm{Cu}_{4} \mathrm{Ti}$ 화 합물이 낮은 계면에너지의 면 관계를 선호하면서 석출되었 음을 설명한다. Ti이 과포화 고용된 $\mathrm{Cu}-\mathrm{Ti}$ 합금을 시효 시, 생성되는 석출물은 스피노달 분해 그리고 준안정상인 $\beta^{\prime}-$ $\mathrm{Cu}_{4} \mathrm{Ti}$ 화합물이 생성되고 시효가 계속될 때, 안정상인 $\beta$ $\mathrm{Cu}_{4} \mathrm{Ti}$ 으로 변태된다 $[18,20]$. 그림 7에 나타낸 바와 같이 시편 내부에 고르게 분포한 제 2 상은 문헌상에 보고된 $\beta^{\prime}-\mathrm{Cu}_{4} \mathrm{Ti}$ 의 전형적인 형태를 가지고 있으며 [17-19], 이 상 이 석출강화효과를 일으킨다는 것을 확인할 수 있다.

그런데 시효 전 $15 \%$ 단면적 감소율로 가공된 시편을 시 효할 경우, 용체화 처리 후 바로 시효한 시편에 비해 12시 간의 시효에서 석출물의 크기가 다소 증가한 양상을 보였 고 48시간 시효한 경우는 석출물이 용체화 처리 후 시효한 시편에 비해 다소 불규칙한 배열을 가지는 것으로 나타났 다. 이는 그림에서 나타낸 바와 같이 슬립 밴드가 불균일 핵생성 사이트로 작용하고, 여기서 석출물이 생성되었음을 의미한다. 특히 12시간의 시효 시(그림 7 (a)와 (c)) 용체화 처리 후 시효한 시편에 비해 석출물의 크기가 평균적으로 큰 것은 석출 초기 슬립 밴드가 핵 생성을 주도하였기 때 문으로 사료된다. 즉 그림 5 의 시효 시간 증가에 따른 경 
도 및 전도도의 증가가 용체화 처리 후 시효한 시편에 비 하여 빠른 이유에 대해 미세구조적인 관점에서 재확인하는 결과라고 할 수 있다. 시효 전 $75 \%$ 로 가공된 시편을 시효 했을 경우, 그림 7 (e)에 나타낸 12시간의 시효에서 다른 두 시편과 명확한 차이가 나타났다. 잔존한 전단 밴드에 마 이크로미터 이하의 상대적으로 큰 석출물이 생성됨을 확인 할 수 있었다. 이러한 경향은 48시간의 시효에서 더욱 현 저하게 나타난다. 즉 결정립 내 균일 핵생성으로 생성된 석 출물보다 전단 밴드에서 불균일 핵생성으로 인한 큰 판형 의 석출물이 생성된 것을 확인할 수 있다. 전단 밴드는 결 정립 내부 그리고 슬립 밴드와 비교하여 결함의 농도가 크 다고 할 수 있다. 즉 결함의 집합체인 전단 밴드는 $\mathrm{Cu}$ 내 용질 및 기지 원자가 원활하게 확산될 수 있는 통로로 이 용된다고 할 수 있다. 현재까지의 결과를 종합하면, 시효 전 가공된 시편은 용체화 처리한 시편에 비해 슬립 및 전 단 밴드가 기지 내 새로운 확산 경로로 작용하여 석출을 용이하게 진행시킨 것으로 사료된다. 그런데 이러한 불균 일 핵생성된 석출물은 시편 전체에서 $1 \mu \mathrm{m}$ 이상의 크기는 발견하기 어려웠다. 따라서 불균일적으로 생성되었지만 그 크기가 크지 않기 때문에 이 석출물은 기계적 특성 향상에 기여할 수 있을 것으로 판단된다. 다음 그림 8 은 용체화 처리 후 시효 전 시편의 가공 유무에 따른 시효 거동 결과, 즉 그림 5 의 결과를 종합하여 나타낸 결과이다. 그림에 나 타내었듯이 시효 전 $75 \%$ 가공한 시편을 시효한 결과, 전 도도와 경도가 그래프의 우상에 위치한 것을 알 수 있다. 그리고 $15 \%$ 가공한 시편 역시 용체화 처리 후 바로 시효 한 것에 비해 경도 및 전도도 값이 우상에 위치함을 알 수 있다. 이 결과는 전위에 의해 생성된 슬립 밴드 그리고 균 일 변형(uniform deformation) 한계를 넘어 가공된 조직에 서 생성된 전단 밴드(shear band)가 불균일 핵성성 사이트 (heterogeneous nucleation site)로 작용하고 석출을 가속화 시켜 경도와 전도도 상승을 동시에 이끈 결과라고 할 수 있다. 또한 그림 5 에 나타낸 시효 시간에 따른 경도 및 전 도도의 변화와 종합하면 시효 전 가공은 시효 시 최고 경 도에 이르는 시간을 효과적으로 단축시킬 수 있었다. 그리 고 그림 7에 나타낸 바와 같이 전단 밴드에서 불균일 핵생 성되고 성장한 석출물의 크기는 $1 \mu \mathrm{m}$ 이하로, 강도 저하 를 야기하기보다는 강도 상승에 기여한 것으로 판단된다. 일반적으로 동합금에서 시효 시 시효 전 가공은 그 효과가 미미하거나 적은 것으로 알려져 있는데 [22-27], 본 연구의 $\mathrm{Cu}-\mathrm{Ti}$ 합금은 시효 전 가공이 매우 효과가 있음이 밝혀졌 다. 그 이유에 관해서는 명확한 추가 분석이 필요하지만 $\mathrm{Cu}-\mathrm{Ti}$ 합금은 스피노달 분해에 의한 석출이 이루어지는 것

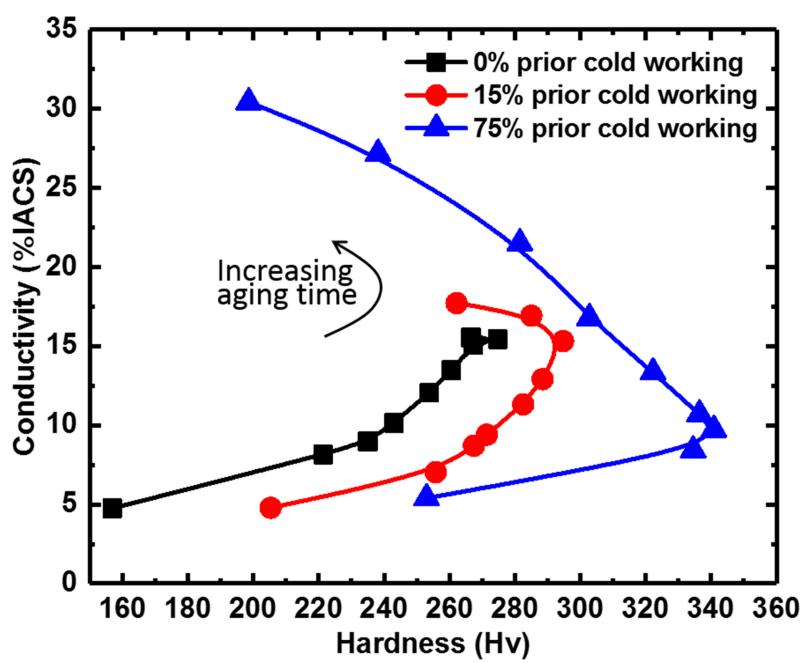

Fig. 8. The combination values of hardness and conductivity of aged $\mathrm{Cu}-3.5 \mathrm{Ti}$ alloy at $450{ }^{\circ} \mathrm{C}$.

이 그 이유로 해석된다. 스피노달 분해는 시효가 진행되는 도중 석출물을 이루는 조성이 풍부한 부분과 희박한 부분 으로 분리되는 과정을 가진다. 이러한 화학적 조성 분리는 미소한 범위의 응력장을 형성하고 전위나 전단 밴드의 이 동을 억제하는 역할을 하게 되어 강도 상승의 원인으로 작 용됨과 함께 그림 7에 나타낸 바와 같이 본 연구에서 의도 적으로 도입된 전위 및 전단 밴드의 이동을 방해하고 또한 석출 핵(precipitation embryo)이 생성될 충분한 시간을 제 공하는 것으로 판단된다. 따라서 이러한 결함이 불균일 핵 생성 사이트로 효과적으로 작용하고, 불균일 핵생성이 석 출을 가속화시켜 단시간 내에 강도와 전도도를 상승시킨 것으로 해석된다.

이와 같이 $\mathrm{Cu}-\mathrm{Ti}$ 합금에서의 시효 전 가공은 석출 시간 의 감소, 최고 경도의 상승을 일으켜 동합금 개발의 본연 의 목적 즉 기계적 특성인 강도 그리고 강도의 상반 특성 인 전도도를 동시에 향상시킬 수 있는 효과적인 방법이라 고 판단된다. 또한 열처리 시 시간과 에너지의 사용을 줄 일 수 있는 시효 시간의 단축을 이룰 수 있는 새로운 방 법으로 기대된다.

\section{5. 결 론}

본 연구에서는 $\mathrm{Cu}-3.5 \mathrm{wt} \% \mathrm{Ti}$ 합금의 시효 전 가공이 시효에 미치는 효과를 살펴보기 위하여 용체화 처리 후 단 면적 감소율 $15 \%$ 그리고 $75 \%$ 로 가공하여 $450^{\circ} \mathrm{C}$ 에서 시 효하였다. 시효 전 가공 유무 그리고 가공 정도에 따른 시 효 시 경도 및 전기 전도도 변화를 분석하였고 그 이유를 
미세조직 분석을 통해 고찰하였다.

1. 시효 전 단면적 감소율 $15 \%$ 를 시행한 시편의 경우, 시효 시간 720 분에서 최고 경도는 $295 \mathrm{Hv}$, 전도도는 $15 \% \mathrm{IACS}$, 그리고 단면적 감소율 $75 \%$ 시편의 경우 시효 시간 30 분에서 $340 \mathrm{Hv}$, 전도도는 $9.7 \% \mathrm{IACS}$ 이며, 반면 에 용체화 처리 직후 시효한 시편은 시효 시간 1440 분에 서 최고 경도는 $275 \mathrm{Hv}$, 전도도는 $15 \% \mathrm{IACS}$ 이었다.

2. 경도와 전도도의 동시 상승은 시효 전 $75 \%$ 가공한 시편에서 용체화 처리 직후 또는 시효 전 $15 \%$ 가공한 시 편에 비해 높게 나타났다.

3. 시효 시 생성된 화합물은 준안정상인 $\beta^{\prime}-\mathrm{Cu}_{4} \mathrm{Ti}$ 과 안 정상인 $\beta-\mathrm{Cu}_{4} \mathrm{Ti}$ 상으로 확인되었고 가공 유무에 상관없이 12 시간의 시효 후 관찰되었다.

4. 시효 시 슬립 밴드와 전단 밴드는 기지 내 12시간의 시효 후에도 잔존하였고 이는 불균일 석출 사이트로 작용 하고 석출 과정을 가속화하였다. 특히 시효 전 균일 변형 한계를 넘어 가공한 시편에 생성된 전단 밴드에서 $1 \mu \mathrm{m}$ 이하이지만 상대적으로 균일 핵생성으로 생성된 석출물보 다 조대한 석출물이 발생하였다.

\section{ACKNOWLEDGEMENTS}

This work was supported principally by Global Frontier R\&D Program (2013M3A6B1078874) on Global Frontier Hybrid Interface Materials R\&D Center funded by the Ministry of Science, ICT, Future Planning and the National Research Foundation of Korea (NRF) grant funded by the Korea government (MSIP) [No. 2018R1A5A6075959], and the Fundamental Research Program (POC2910) of the Korean Institute of Materials Science (KIMS).

\section{REFERENCES}

1. S. Z. Han, J. Lee, M. Goto, S. H. Lim, J. H. Ahn, S. Kim, and K. Kim, Phil. Mag. Lett. 96, 196 (2016).

2. S. Z. Han, H. Joh, J. H. Ahn, J. Lee, S. M. Kim, S. H. Lim, and Y. G. Son, J. Alloy. Compd. 622, 384 (2015).

3. S. Z. Han, K. H. Kim, J. Kang, H. Joh, S. M. Kim, J. H. Ahn, J. Lee, S. H. Lim, and B. Han, Sci. Rep. 5, 17364 (2015).

4. S. Z. Han, J. H. Ahn, Y. S. You, J. Lee, M. Goto, K. Kim, and S. Kim, Met. Mater. Int. 24, 23 (2018).

5. S. Z. Han, S. H. Lim, S. Kim, J. Lee, M. Goto, H. G. Kim,
B. Han, and K. Kim, Sci. Rep. 6, 30907 (2016).

6. S. Z. Han, J. Lee, S. H. Lim, J. H. Ahn, K. Kim, and S. Kim, Met. Mater. Int. 22, 1049 (2016).

7. Q. Lei, Z. Li, T. Xiao, Y. Pang, Z. Q. Xiang, W. T. Qiu, and Z. Xiao, Intermetallics 42, 77 (2013).

8. S. Suzuki, N. Shibutani, K. Miura, M. Isshiki, and Y. Waseda, J. Alloy. Compd. 417, 116 (2006).

9. J. H. Ahn, D. W. Kim, M. S. Kim, J. H. Hwang, and S. Z. Han, Korean J. Met. Mater. 55, 537 (2017).

10. Y. Kim, J. Kwon, D. Yoo, S. Park, D. Lee, and D. Lee, Korean J. Met. Mater. 55, 165 (2017).

11. J. D. Verhoeven, S. C. Chueh, and E. D. Gibson, J. Meter. Sci. 24, 1748 (1989).

12. D. P. Lu, J. Wang, W. J. Zeng, Y. Lio, L. Lu, and B. D. Sun, Mat. Sci. Eng. A 421, 254 (2006).

13. L. Yagmur, Mat. Sci. Eng. A 523, 65 (2009).

14. P. Behjati, H. V. Dastjerdi, and R. Mahdavi, J. Alloy. Compd. 505, 739 (2010).

15. S. nagarjuna and K. balasubramanian, J. Mater. Sci. 34, 2929 (1999).

16. W. A. Soffa and D. E. Laughlin, Prog. Mater. Sci. 49, 347 (2004).

17. S. Nagarjuna, M. Srinivas, K. Balasubramanian, and D. S. Sarma, Mat. Sci. Eng. A 259, 34 (1999).

18. S. Semboshi, E. Hinamoto, and A. Iwase, Mater. Lett. 131, 90 (2014).

19. T. J. Konno, R. Nishio, S. Semboshi, T. Ohsuna, and E. Okunishi, J. Mater. Sci. 43, 3761 (2008).

20. S. Semboshi, M. Ishikura, S. Sate, K. Wagatsuma, and T. Takasugi, Mater. Charact. 82, 23 (2013).

21. S. Semboshi and T. Takasugi, J. Alloy. Compd. 580, 397 (2013).

22. S. A. Lockyer and F. W. Noble, J. Mater. Sci. 29, 218 (1994).

23. F. Huang, J. Ma, H. Ning, Y. Cao, and Z. Geng, Mater. Lett. 57, 2135 (2003).

24. Y. Fujimura, T. Matsui, S. Semboshi, Y. Okamoto, K. Nishida, Y. Yamamoto, and A. Iwase, J. Alloy. Compd. 682, 805 (2016).

25. V. C. Srivastava, A. Schneider, V. Uhlenwinkel, S. N. Ojha, and K. Bauckhage, J. Mater. Process. Technol. 147, 174 (2004).

26. S. Suzuki, N. Shibutani, K. Mimura, M. Isshiki, and Y. Waseda, J. Alloy. Compd. 417, 116 (2006).

27. S. Xu, H. Fu, Y. Wang, and J. Xie, Mat. Sci. Eng. A 726, 208 (2018). 